Int. J. Dev. Biol. 55: 477-482

doi: $10.1387 / \mathrm{ijdb} .103225 \mathrm{yz}$

\title{
Cancer stem cells and angiogenesis
}

\author{
YUE ZHAO\#, QI BAO\#, ANDREA RENNER, PETER CAMAJ, MARTIN EICHHORN, IVAN ISCHENKO, \\ MARTIN ANGELE, AXEL KLEESPIES, KARL-WALTER JAUCH and CHRISTIANE BRUNS*
}

\author{
Department of Surgery, Klinikum Grosshadern, LMU Munich, Munich, Germany
}

\begin{abstract}
Cancer stem cells (CSCs) or tumor initiating cells were identified and characterized as a unique subpopulation with stem cell features in many types of cancer. Current CSC studies provide novel insights regarding tumor initiation, progression, angiogenesis, resistance to therapy and interplay with the tumor micro-environment. A cancer stem cell niche has been proposed based on these findings. The niche provides the soil for CSC self-renewal and maintenance, stimulating essential signaling pathways in CSCs and leading to secretion of factors that promote angiogenesis and long term growth of CSCs. We present evidence which has emerged over the past 5 years indicating interaction of CSCs with angiogenesis in the proposed "vascular niche". Based on these findings, targeting the "cancer stem cell niche" by combining an individualized anti-CSC approach with treatment of their microenvironment may represent a novel therapeutic strategy against solid tumor systems.
\end{abstract}

KEY WORDS: cancer stem cell, angiogenesis, cancer vascular niche/microenvironment

\section{Introduction}

Cancer is a complicated disease in which abnormal cells divide without control and are able to invade other tissues - spreading to other parts of the body through the blood and lymph, developing to the most devastating stage and leading cause of death in cancer - metastasis.

Even systemic anticancer therapies after primary tumor resection often fail because of recurrence and over-curing side effects. Increasing evidence indicates the existence of small subpopulations of cells endowed with unique self-renewal capacity, tumorigenesis, and radio- and chemotherapy resistance, defined as cancer stem cells (CSCs) or tumor initiating cells. These cells are predicted as a critical population of tumor cells which might mainly drive each step of tumor programming, including neoplasm initiation, tumor growth and metastasis (Al-Hajj et al., 2003, Lapidot et al., 1994, Singh et al., 2004). Initially, cancer stem cells were identified in hematological malignancies, then they were isolated subsequently from many organs including breast, prostate, brain, gastrointestinal, liver, lung, skin and ovarian cancer.

Tumor development relies on angiogenesis. The growth of blood vessels is essential for organ growth and repair while the lymphatic vasculature also forms the vessel network that participates in immune defense. Both angiogenesis and lymphangiogenesis play an important role in the process of numerous malignances (Alitalo et al., 2005, Carmeliet, 2005). Several studies showed that significant therapeutic advantage can be achieved by treatment with angiogenesis inhibitors such as sorafenib, sunitinib, and bevacizumab (Escudier et al., 2007, Faivre et al., 2007, Hurwitz et al., 2004, Sandler et al., 2006). Accumulating evidence has shown that CSCs interact closely with angiogenesis, especially in glioma, a solid tumor that is highly lethal, difficult to treat and intimately dependent on angiogenesis. Recent discoveries revealed

Abbreviations used in this paper: ABCG2, ATP-binding cassette sub-family G member 2; ALDH1, Aldehyde dehydrogenase-1; ALK, Activin-like kinase; BMP, Bone morphogenetic protein; BMPR, Bone morphogenetic protein receptor; CD24, CD31, CD34, CD44, CD105, CD133, cluster of differentiation; CSCs, cancer stem cells; CXCR4, Chemokine (C-X-C motif) receptor 4; DAPT: $\gamma$-secretase inhibitor, N-[N-(3,5-Difluorophenacetyl)-L-alanyl]-S-phenylglycine t-butyl ester; EMT, Epithelial-mesenchymal transition; EPC, endothelial progenitor cells; EpCAM, Epithelial cell adhesion molecule; HER1/HER2, human epidermal growth factor receptor; HSC/HPC, hepatic stem/progenitor cell; MMP, Matrix metalloproteinase; MVD, microvessel density; NICD: Notch intracellular domain; NOD-SCID, non-obese diabetic severe combined immunodeficiency; OPN, osteopontin; Sca 1, Spinocerebellar ataxia type 1; SCLGC, stem cell-like glioma cells; SDF-1, stromal-derived-factor-1; TGF $\beta$, Transforming growth factor $\beta$; TMAs, tissue microarrays; VEGF, Vascular endothelial growth factor; ZEB1, Zinc finger E-box-binding homeobox 1.

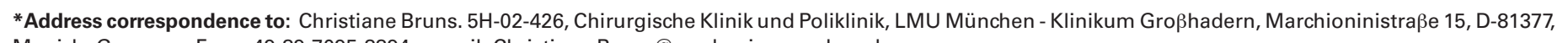
Munich, Germany. Fax: +49-89-7095-8894. e-mail: Christiane.Bruns@med.uni-muenchen.de

\# Note:These authors contributed equally to this work.

Final, author-corrected PDF published online: 24 June 2011.

ISSN: Online 1696-3547, Print 0214-6282

(C) 2011 UBC Press

Printed in Spain 
the interplay among CSCs, angiogenesis and tumor vasculature based on this tumor model.

\section{Cancer stem cells programming in cancer}

Cancer originates from cells accumulating multiple mutations which initiate uncontrolled proliferation and resistance to apoptosis undergoing both genetic and epigenetic aberration within unique microenvironments. In addition, these cells must obtain selfrenewing ability as stem-cell-like properties (Marotta and Polyak, 2009). CSCs also appear to have activated common signaling pathways as Notch, Hedgehog and Wnt like in normal stem cells (Klonisch et al., 2008). They share similar gene and epigenetic profiles (Bloushtain-Qimron et al., 2008) and even express related surface and functional markers (CD133, ALDH1, CD44, EpCAM,

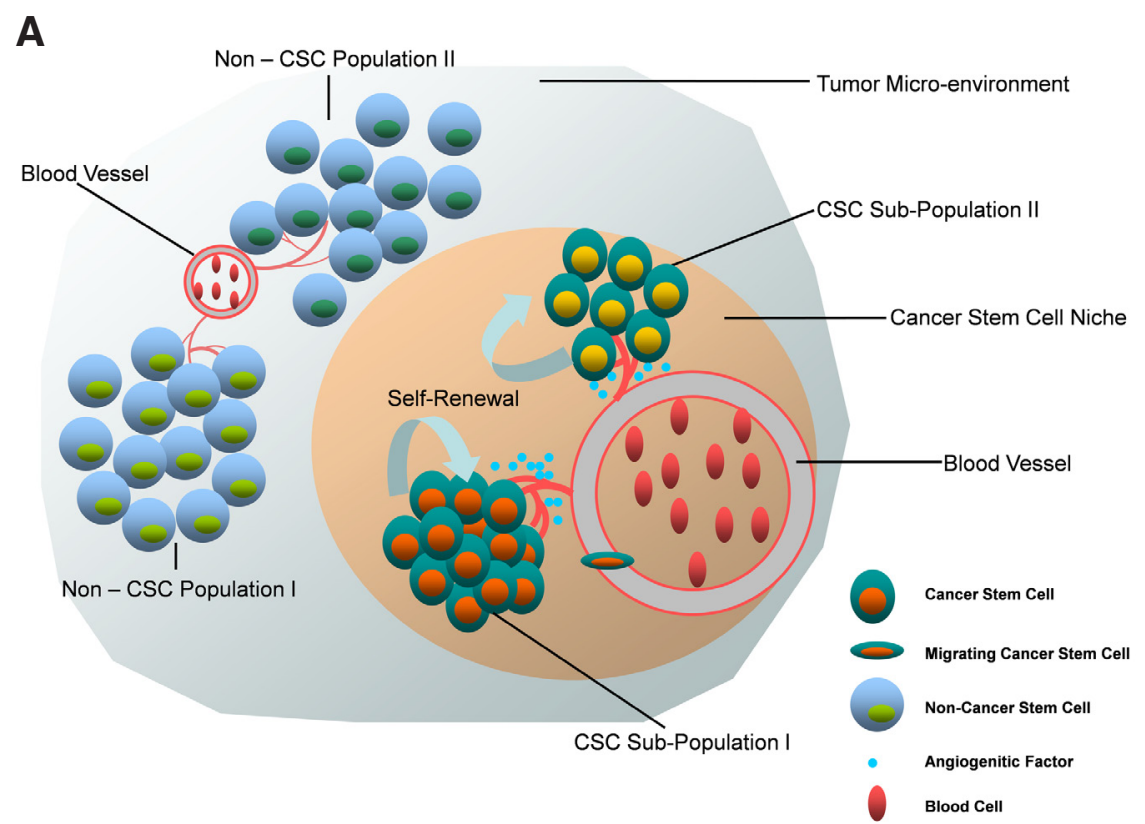

B

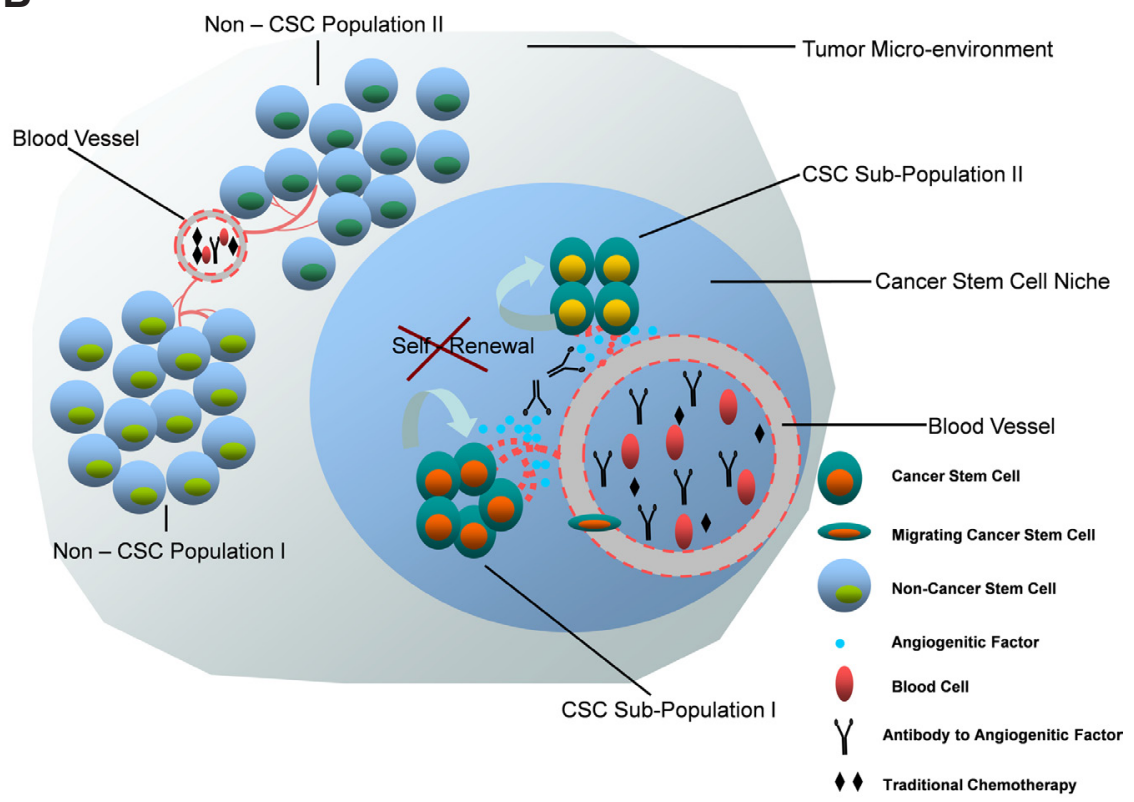

Sca1 and ABCG2) in multiple tissue types (Marotta and Polyak, 2009, Visvader and Lindeman, 2008). Some of these markers also have been proposed to metastasis,angiogenesis, chemo resistance and tissue differentiation. For instance, CD44, known as an adhesion molecule, utilized in lyphocyte "homing", might assist carcinoma cells in haematogenous dissemination and interact with other carcinogenesis factors like MMP-9,VEGF and OPN (Eccles, 2004). Although the limitation of mouse injection assays was reported (with an impaired or imcompatible immune system), the isolation and serial transplantation of CSC populations into animal models have displayed tumor initiation potential (Vermeulen et al., 2008). Some researchers noted that the CSCs have significant stronger oncogenic abilities than corresponding non-stem-cell-like tumor cells. Even in one tumor there might be more than one population of CSCs with a range of markers involved in tumorigenesis (Fig. 1), which might contribute to radio- and/or chemotherapy failure.

Recently, Chen et al. revealed that individual glioblastoma could harbor a series of phenotypically distinct self-renewing cell types that promote a range of tumor growth pattern. Both CD133+ and CD133- cell types generate highly aggressive tumors (Chen et al., 2010). In addition, Al-Hajj et al. isolated a $11 \%-35 \%$ population of CD44+ / CD24-/low cells in breast cancer and injected a minimum cell amount of 200 cells into NOD-SCID mice for tumor formation (Al-Hajj et al., 2003), while Ginestier et al. identified 3\%-10\% ALDH1+ breast cancer cells and demonstrated that at least an amount of 500 cells is necessary to generate tumors in the same animal model (Ginestier et al., 2007).

Recent data also indicate that cancer stem cells are probably involved in metastasis. Epithelialmesenchymal transition (EMT) has been identified at the invasive edge of tumors and plays an important role in the process of metastasis (Gentile and Comoglio, 2004, Visvader and Lindeman, 2008). The evidence of breast CSCs expressing EMT markers and EMT-activator ZEB1 promoting tumor initiating capacity of pancreatic and colorectal cancer cells, links EMT to cancer stem cells supporting the concept of migrating / metastatic cancer stem cells (Mani et al., 2008). In addition, chemokines also contribute to invasion

Fig. 1. Model of anti-cancer stem cell niche therapy in tumor. The heterogeneity in tumor cells also exists in cancer stem cells (Chen et al., 2010). Tumor cells rely on vasculature and harbor a unique microenvironment. Cancer stem cells, like normal neural stem cells, may reside in a vascular niche named as 'Cancer stem cell niche' (Calabrese et al., 2007). (A) Relationship between CSCs and theirniche may be bidirectional: CSCs generate angiogenic factors (i.e. VEGF) to stimulate angiogenesis and the tumor vasculature supports maintaining CSC self-renewal and maintenance. (B) Anti-angiogenic therapeutics combined with other chemotherapy drugs will disrupt angiogenesis and also interrupt the vasculaturederived CSC maintenance (Eyler and Rich, 2008). 
and metastasis-promotion by function as autocrine and paracrine growth factors enhancing those process, even could determine the location of secondary tumors (Opdenakker and Van Damme, 2004). Recently, Hermann et al. found a subset of CD133+/CXCR4+ pancreatic cancer stem cells of the overall CSC population located at the invasive edge of tumors, which seem to be more responsible for metastasis than for tumorigenicity (Hermann et al., 2007). CXCR4 positive might be responsible for the signals that CSC receives from the microenvironment, partly, determines which cancer cell possesses the capacity to self-renew.

Furthermore, cancer stem cells are thought as the origin of post-therapeutic tumor recurrence (Wicha et al., 2006). On the one hand, numerous results have shown lately that some cancer stem cells are resistant to either radiation or chemotherapy. Interestingly, Yu F. et al. discovered that breast cancer patients have a higher percentage of cancer stem cell-like properties after chemotherapy (Yu et al., 2007). These findings indicate that therapy might be less effective on eliminating cancer stem cells than non-stem-celllike cancer cells. On the other hand, there are a couple of drugs which seem to target specifically cancer stem cells. For instance, lapatinib is used as HER1/HER2 inhibitor, particularly applying in HER2 positive breast cancer patients. Interestingly, breast cancer stem cells usually increase after traditional chemotherapy while they decrease under lapatinib treatment, and in some patients lapatinib seems to show even a complete response (Li et al., 2008).

All facts mentioned above in this part provide current evidence that we start to understand the proposed roles of cancer stem cells in tumorigenesis, metastasis and disease recurrence. The identification of CSCs potentially clarifies novel mechanisms in tumor biology and helps to develop future therapeutic strategies for solid cancers.

\section{Cancer stem cells promote tumor angiogenesis}

Tumor angiogenesis is critical for tumor growth and maintenance (Kaur et al., 2005), also applied as important cellular parameters of tumorigenesis (Bergers et al., 1998). Cancer stem cells show greater potential for tumor initiation and formation than non-stem cell like tumor cells. Gliomas are exemplary for the significant impact of angiogenesis on tumor progression with impressively elevated levels of vascular endothelial growth factors (VEGFs) (Plate et al., 1994, Plate etal., 1992). Although VEGFs are expressed at elevated levels by endothelial cells engaged in angiogenesis and circulating bone marrow derived endothelial progenitor cells, many types of human cancer cells can also secrete VEGFs (Kerbel, 2008). In these regards, it is logical to suggest that cancer stem cells can function on angiogenesis. Recently, an emerging area of research supports that CSCs, besides their self-renewal and proliferative capabilities, may promote tumor angiogenesis.

As primly mentioned in stem cell-like glioma cells (SCLGC), Bao et al. observed that CD133-enriched SCLGC are located in proximity to blood vessels. Compared with CD133-SCLGC, CD133+SCLGC generated tumors with increasing tumor vascularity, necrosis and hemorrhage. The VEGF expression in CD133+ SCLGC was 10-20 folds up-regulated, combined with a dramatically increased vascular density identified by CD31 staining. Furthermore, therapy with VEGF neutralizing antibody (bevacizumab) can deplete SCLGC-induced vascular endothelial cell migration and tube formation.

In vivo results additionally display that bevacizumab specifically inhibits the tumor growth of SCLGC-derived xenografts. VEGF receptors were not detected in SCLGC, thus targeting VEGF may have more direct effects on endothelial cells or other cancer cells in gliomas as shown in Fig. 1 (Bao et al., 2006). Other studies support this finding in CSCs isolated from U87 glioma human cell lines and GL261 murine glioma cell lines (Pellegatta et al., 2006, Yao et al., 2008). Chris et al. additionally investigated that CSCs contribute to tumor vascular development in glioma. The work revealed that tumor with larger CSC population recruited a substantially higher amount of endothelial progenitor cells (EPC), suggesting that CSCs promote local angiogenesis and EPC mobilization via stimulating proangiogenic factors such as VEGF and SDF-1 (Folkins et al., 2009).

Related research has explored this phenomenon using high throughput assays in liver cancer, qRT-PCR assessment and tissue microarray (TMAs) validation (Yang et al., 2010). In the high hepatic stem/progenitor cell (HSC/HPC) profile group (CD133, Nestin CD44 and ABCG2), the MVD and angiogenic factors (VEGF and PD-ECGF) are significantly higher than in the low HSC/HPC profile group and related to a poor prognosis. Both stemness and angiogenesis associated factors might be potential biomarkers for clinical prediction (Yang et al., 2010). These data partly indicate that tumor angiogenesis is induced by cancer stem cells, expressing angiogenic factors to the cancer microenvironment (Fig. 1)

\section{Cancer stem cells in vascular niche}

The first notion of tumor microvascular-environment goes back to 1940 s, when Scherer suggested that glioblastoma cells grow

TABLE 1

ANGIOGENIC MARKERS EXPRESSED BY CANCER STEM CELLS (CSC)

\begin{tabular}{|c|c|c|c|c|}
\hline Tumor Type & CSC marker & Angiogenic marker & Indication & Reference \\
\hline Malignant glioma & CD133 & VEGF & CSCs co-expressed with angiogenic markers \& cause MVD increase & (Bao et al., 2006) \\
\hline Glioblastoma & Nestin & VEGF & CSCs induce angiogenesis & (Oka et al., 2007) \\
\hline Melanoma & $\begin{array}{l}\text { CD133 } \\
\text { ABCG2 }\end{array}$ & $\begin{array}{l}\text { VEGF/VEGFR-2 } \\
\text { Ang1/2 } \\
\text { Tie2 }\end{array}$ & CSC and angiogenic markers co-expressed & (Monzani et al., 2007) \\
\hline $\begin{array}{l}\text { Oligodendroglioma \& } \\
\text { Glioblastoma }\end{array}$ & $\begin{array}{l}\text { CD133 } \\
\text { Nestin }\end{array}$ & CD34 & CSCs close to vessels \& cause MVD increase & (Calabrese et al., 2007) \\
\hline Pancreatic cancer & CD133 & VEGF-C & CSCs cause MVD increase & (Maeda et al., 2008) \\
\hline Hepatocellular carcinoma & $\begin{array}{l}\text { CD133 } \\
\text { ABCG2 } \\
\text { Nestin } \\
\text { CD44 }\end{array}$ & $\begin{array}{l}\text { VEGF } \\
\text { PD-ECGF }\end{array}$ & CSC and angiogenic markers co-expressed & (Yang et al., 2010) \\
\hline
\end{tabular}

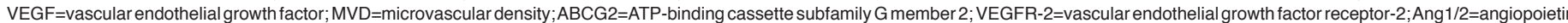
1/2; PD-ECGF=platelet-derived endothelial cell growth factor. 
into the site which is surrounded by blood vessels (perivascular satellitosis). From then on, abundant reports support the theory that the neo-vascularity formed around tumors play a special role in cancer development and metastasis. Recently it was called the 'cancer vascular niche'.

Current CSC research generates a large amount of data that show the relationship between cancer stem cells and the cancer vascular niche (Fig. 1). For instance, in Calabrese's research, the oligodendroglioma and glioblastoma stem cells which expressed the major intermediate filament protein Nestin are located in close proximity to CD34+ capillaries and are positively correlated to microvessel density (MVD) (Calabrese et al., 2007). This result strongly supports the hypothesis that CSCs are located within a vascular niche.

As mentioned above, cancer stem cells express vascular-related

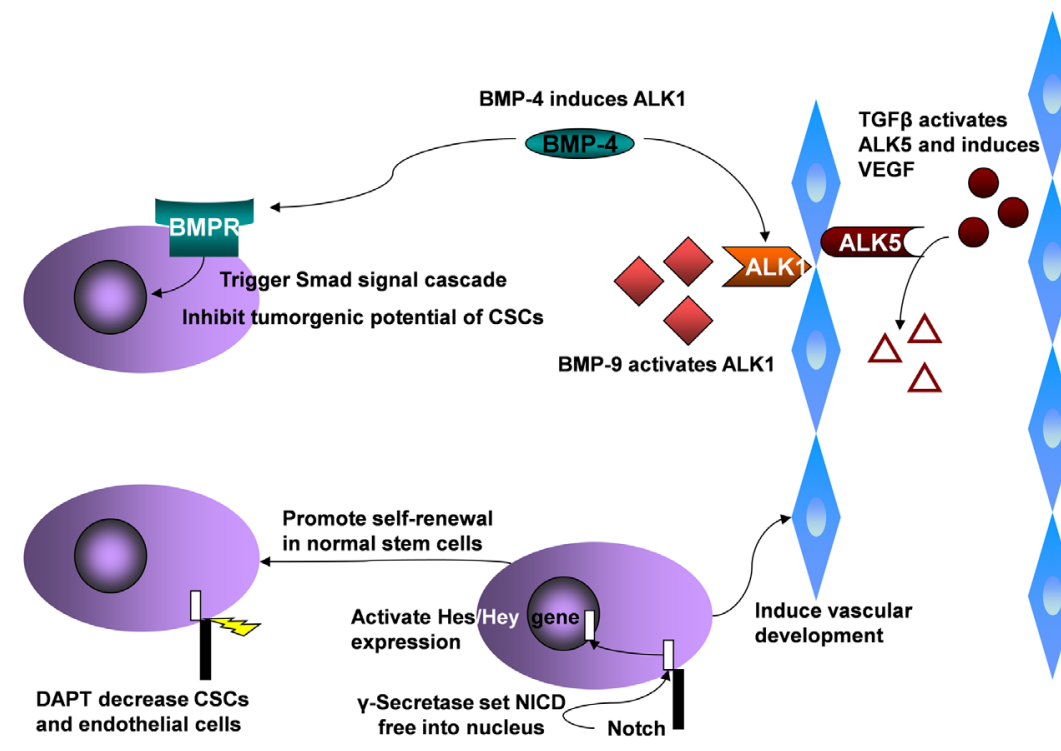

BMP-4 BMP-4: Bone morphogenetic protein-4
BMP-9: Bone morphogenetic protein-9
ALK5 ALK5: Activin-like kinase 5
TGF $\beta$ : Transforming growth factor $\beta$

Fig. 2. Signal pathway relationship of cancer stem cells (CSCs) and angiogenesis. BMP-9 suppresses VEGF expression by the BMP-9/ALK1 pathway against the effect of the TGFB1/ALK5 pathway which can enhance VEGF expression and angiogenesis. In between these two pathways, the key role of the balance is BMP-4, which can keep the vascular integrity. Meanwhile BMP-4 inhibits the tumorigenic potential of glioblastoma cancer stem cells through the BMP-4/BMPR/SMAD signaling pathway. Notch induces vascular development and normal stem cell survival through the Notch/NICD/Hes/Hey signaling pathway. Notch inhibitor DAPT ( $\gamma$-secretase inhibitor), not only decreases the self-renewal ability of tumor cells and the number of CD133+ cells, it also decreases the expression of vascular markers like CD105, CD31, von Willebrand factor, et al. This figure was drawn according to (Androutsellis-Theotokis et al., 2006, Gridley, 2007, Hovinga et al., 2010, Piccirillo et al., 2006, Shao et al., 2009). agents in order to induce neo-vascular growth and establish an aberrant vascular niche, as shown in Table 1. On the other hand,

ute to maintenance and further proliferation of cancer stem cells. Calabrese et al. set up a co-culture model for investigation of the of CSCs (Calabrese et al., 2007). However, the authors only show that anti-angiogenic therapy targeting VEGF could deplete the tumor of DC101, targeting the VEGFR2 in C6 rat glioma xenograft tumors (Folkins et al., 2007), indicating the importance of the dual effect of anti-angiogenic therapy with efficacy against tumor angiogenesis and CSCs expressing pro-angiogenic factors and receptors. Nevertheless, further investigation within this area is necessary.

Up to now, there are more than 5 ways of new vessel formation, including sprouting, intussusceptive angiogenesis, the recruitment of endothelial progenitor cells (EPCs), vessel cooption and vasculogenic mimicry (Hillen and Griffioen, 2007). As mentioned above, CSCs express VEGF to induce angiogenesis potentially through sprouting or intussusception of the preexisting vasculature or through recruitment of EPCs. Besides these possibilities, we hypothesize that CSCs might participate in vasculogenic mimicry to induce angiogensis. This hypothesis is based on the data shown in Table 1, where many CSC biomarkers are co-expressed with angiogenic markers. This two-side theory of the CSC vascular niche needs to be further evaluated by well-designed experiments.

\section{Signal pathway of cancer stem cells and angiogenesis}

As discussed above, there are still some dark corners which need to be explored within CSCs vascular niche. For example: what is the exact role of vascular endothelial cells in maintenance and proliferation of cancer stem cells? How can they influence CSCs? Which is the underlying important ligand-receptor interaction or signaling pathway?

One of the critical pathways of CSCs and angiogenesis is BMP (bone morphogenic protein) signaling. BMP initially played a role in bone formation, now it also shows an important function in inhibition of angiogenesis. According to the report of Shao et al., BMP-9 can suppress VEGF expression by the BMP-9/ALK1 pathway, whereas the TGF $\beta 1 /$ ALK5 pathway enhances VEGF expression and angiogenesis. In between these two pathways, the key role of the balance is BMP-4, which can keep the vascular integrity (Shao et al., 2009). Interestingly, Piccirillo's data show that BMP-4 inhibits the tumorigenic potential of glioblastoma cancer stem cells through the BMP-4/BMPR/SMAD signaling pathway (Piccirillo et al., 2006). These results indicate the BMP plays a vital role in CSC tumorigenesis and 
angiogenesis, however, further experiments need to be done to show the fundamental cause and effect.

Another important mechanism is the Notch signaling pathway. The Notch/NICD/Hes/Hey signaling pathway is included in vascular development and normal stem cell survival (Androutsellis-Theotokis et al., 2006, Gridley, 2007). Recently, Hovinga et al. showed that the Notch pathway combines glioblastoma angiogenesis and cancer stem cell self-renewal. Notch inhibitor DAPT ( $\gamma$-secretase inhibitor) not only leads to a reduction of the self-renewal ability of cancer stem cells and the number of CD133+ tumor cells, it also reduced the expression of vascular markers such as CD105, CD31, von Willebrand factor (Hovinga et al., 2010). These two pathways are both related to CSCs and angiogenesis (schematic chart is shown in Fig. 2), but there are still much more signals associated with CSCs and angiogenesis, respectively. In order to explore the entire network of signals within CSCs and angiogenesis, more research effort is still needed.

\section{Perspectives}

Advanced technologies and daily developed experimental systems currently used in cancer research will speed up the understanding of the main principles of cancer stem cells involving in tumor progression (Crnic and Christofori, 2004). Meanwhile, further research on the interaction of cancer stem cells and angiogenesis will help to develop some novel therapeutic strategies against cancer as a bilateral benefit. Regarding the close interaction between CSCs and tumor angiogenesis it seems so far reasonable to combine traditional radio- and chemotherapy with anti-angiogenic therapy. With further investigation of isolation and identification of surface or functional markers of CSCs, localization and visualization of different types of CSCs in situ, particularly in solid tumor systems, it can potentially be facilitated in the clinical routine with the major goal to develop an individualized therapeutic approach. Since CSCs are associated to therapy resistance and disease recurrence, the development of clinically useful inhibitors to target the individual CSC niche should be prioritized (Hida et al., 2004, St Croix et al., 2000, Xiong et al., 2009). Furthermore, potential anti-CSC therapy should have minimal or no effect on normal stem cells. The therapy must be applied safely after testing for the sensitivity of normal and cancer stem cells.

It is probably one of the most visionary therapeutic strategies against solid tumor systems to combine an individualized anti-CSC approach by targeting their microenvironment or so called "CSC niche" with conventional radio- or chemotherapy for the remaining non CSC tumor cell proportion.

\section{References}

AL-HAJJ, M., WICHA, M.S., BENITO-HERNANDEZ, A., MORRISON, S.J. and CLARKE, M.F. (2003). Prospective identification of tumorigenic breast cancer cells. Proc Natl Acad Sci USA 100: 3983-3988.

ALITALO, K., TAMMELA, T. and PETROVA, T.V. (2005). Lymphangiogenesis in development and human disease. Nature 438: 946-953.

ANDROUTSELLIS-THEOTOKIS, A., LEKER, R.R., SOLDNER, F., HOEPPNER, D.J., RAVIN, R., POSER, S.W., RUEGER, M.A., BAE, S.K., KITTAPPA, R. and MCKAY, R.D. (2006). Notch signalling regulates stem cell numbers in vitro and in vivo. Nature 442: 823-826.

BAO, S.D., WU, Q.L., SATHORNSUMETEE, S., HAO, Y.L., LI, Z.Z., HJELMELAND, A.B., SHI, O., MCLENDON, R.E., BIGNER, D.D. and RICH, J.N. (2006). Stem cell-like glioma cells promote tumor angiogenesis through vascular endothelial growth factor. Cancer Res 66: 7843-7848.

BERGERS, G., HANAHAN, D. and COUSSENS, L.M. (1998). Angiogenesis and apoptosis are cellular parameters of neoplastic progression in transgenic mouse models of tumorigenesis. Int J Dev Biol 42: 995-1002.

BLOUSHTAIN-QIMRON, N., YAO, J., SNYDER, E.L., SHIPITSIN, M., CAMPBELL, L.L., MANI, S.A., HU, M., CHEN, H., USTYANSKY, V., ANTOSIEWICZ, J.E. et al. (2008). Cell type-specific DNA methylation patterns in the human breast. Proc Natl Acad Sci USA 105: 14076-14081.

CALABRESE, C., POPPLETON, H., KOCAK, M., HOGG, T.L., FULLER, C., HAMNER, B., OH, E.Y., GABER, M.W., FINKLESTEIN, D., ALLEN, M. et al. (2007). A perivascular niche for brain tumor stem cells. Cancer Cell 11: 69-82.

CARMELIET, P. (2005). Angiogenesis in life, disease and medicine. Nature 438: 932-936.

CHEN, R., NISHIMURA, M.C., BUMBACA, S.M., KHARBANDA, S., FORREST, W.F., KASMAN, I.M., GREVE, J.M., SORIANO, R.H., GILMOUR, L.L., RIVERS, C.S. et al. (2010). A hierarchy of self-renewing tumor-initiating cell types in glioblastoma. Cancer Cell 17: 362-375

CRNIC, I. and CHRISTOFORI, G. (2004). Novel technologies and recent advances in metastasis research. Int $J$ Dev Biol 48: 573-581.

ECCLES, S.A. (2004). Parallels in invasion and angiogenesis provide pivotal points for therapeutic intervention. Int J Dev Biol 48: 583-598.

ESCUDIER, B., EISEN, T., STADLER, W.M., SZCZYLIK, C., OUDARD, S., SIEBELS, M., NEGRIER, S., CHEVREAU, C., SOLSKA, E., DESAI, A.A. et al. (2007). Sorafenib in advanced clear-cell renal-cell carcinoma. N Engl J Med 356: 125-134.

FAIVRE, S., DEMETRI, G., SARGENT, W. and RAYMOND, E. (2007). Molecular basis for sunitinib efficacy and future clinical development. Nat Rev Drug Discov 6: 734-745.

FOLKINS, C., MAN, S., XU, P., SHAKED, Y., HICKLIN, D.J. and KERBEL, R.S. (2007). Anticancer therapies combining antiangiogenic and tumor cell cytotoxic effects reduce the tumor stem-like cell fraction in glioma xenograft tumors. Cancer Res 67: 3560-3564.

FOLKINS, C., SHKED, Y., MAN, S., TANG, T., LEE, C.R., ZHU, Z.P., HOFFMAN, R.M. and KERBEL, R.S. (2009). Glioma Tumor Stem-Like Cells Promote Tumor Angiogenesis and Vasculogenesis via Vascular Endothelial Growth Factor and Stromal-Derived Factor 1. Cancer Res 69: 7243-7251.

GENTILE, A. and COMOGLIO, P.M. (2004). Invasive growth: a genetic program. Int J Dev Biol 48: 451-456.

GINESTIER, C., HUR, M.H., CHARAFE-JAUFFRET, E., MONVILLE, F., DUTCHER, J., BROWN, M., JACQUEMIER, J., VIENS, P., KLEER, C.G., LIU, S. et al. (2007). ALDH1 is a marker of normal and malignant human mammary stem cells and a predictor of poor clinical outcome. Cell Stem Cell 1: 555-567.

GRIDLEY, T. (2007). Notch signaling in vascular development and physiology. Development 134: 2709-2718.

HERMANN, P.C., HUBER, S.L., HERRLER, T., AICHER, A., ELLWART, J.W., GUBA, M., BRUNS, C.J. and HEESCHEN, C. (2007). Distinct populations of cancer stem cells determine tumor growth and metastatic activity in human pancreatic cancer Cell Stem Cell 1: 313-323.

HIDA, K., HIDA, Y., AMIN, D.N., FLINT, A.F., PANIGRAHY, D., MORTON, C.C. and KLAGSBRUN, M. (2004). Tumor-associated endothelial cells with cytogenetic abnormalities. Cancer Res 64: 8249-8255.

HILLEN, F. and GRIFFIOEN, A.W. (2007). Tumour vascularization: sprouting angiogenesis and beyond. Cancer Metastasis Rev 26: 489-502.

HOVINGA, K.E., SHIMIZU, F., WANG, R., PANAGIOTAKOS, G., VAN DER HEIJDEN, M., MOAYEDPARDAZI, H., SOFIA CORREIA, A., SOULET, D., MAJOR, T., MENON, J. et al. (2010). Inhibition of Notch Signaling in Glioblastoma Targets Cancer Stem Cells Via an Endothelial Cell Intermediate. Stem Cells 28:1019-1029.

HURWITZ, H., FEHRENBACHER, L., NOVOTNY, W., CARTWRIGHT, T., HAINSWORTH, J., HEIM, W., BERLIN, J., BARON, A., GRIFFING, S., HOLMGREN, E. et al. (2004). Bevacizumab plus irinotecan, fluorouracil, and leucovorin for metastatic colorectal cancer. N Engl J Med 350: 2335-2342.

KAUR, B., KHWAJA, F.W., SEVERSON, E.A., MATHENY, S.L., BRAT, D.J. and VAN MEIR, E.G. (2005). Hypoxia and the hypoxia-inducible-factor pathway in glioma growth and angiogenesis. Neuro-Oncology 7: 134-153.

KERBEL, R.S. (2008). Molecular origins of cancer: Tumor angiogenesis. N Engl J Med 358: 2039-2049. 


\section{Y. Zhao et al.}

KLONISCH, T., WIECHEC, E., HOMBACH-KLONISCH, S., ANDE, S.R., WESSELBORG, S., SCHULZE-OSTHOFF, K. and LOS, M. (2008). Cancer stem cell markers in common cancers - therapeutic implications. Trends Mol Med 14: 450-460.

LAPIDOT, T., SIRARD, C., VORMOOR, J., MURDOCH, B., HOANG, T., CACERESCORTES, J., MINDEN, M., PATERSON, B., CALIGIURI, M.A. and DICK, J.E. (1994). A cell initiating human acute myeloid leukaemia after transplantation into SCID mice. Nature 367: 645-648.

LI, X., LEWIS, M.T., HUANG, J., GUTIERREZ, C., OSBORNE, C.K., WU, M.F., HILSENBECK, S.G., PAVLICK, A., ZHANG, X., CHAMNESS, G.C. et al. (2008). Intrinsic resistance of tumorigenic breast cancer cells to chemotherapy. $J$ Natl Cancer Inst 100: 672-679.

MANI, S.A., GUO, W., LIAO, M.J., EATON, E.N., AYYANAN, A., ZHOU, A.Y., BROOKS, M., REINHARD, F., ZHANG, C.C., SHIPITSIN, M. et al. (2008). The epithelial-mesenchymal transition generates cells with properties of stem cells. Cell 133: 704-715.

MAROTTA, L.L. and POLYAK, K. (2009). Cancer stem cells: a model in the making. Curr Opin Genet Dev 19: 44-50.

OPDENAKKER, G. and VAN DAMME, J. (2004). The countercurrent principle in invasion and metastasis of cancer cells. Recent insights on the roles of chemokines. Int J Dev Biol 48: 519-527.

PEllegattA, S., POLIANI, P.L., CORNO, D., MENGHI, F., GHIELMETTI, F., SUAREZ-MERINO, B., CALDERA, V., NAVA, S., RAVANINI, M., FACCHETTI, F. et al. (2006). Neurospheres enriched in cancer stem-like cells are highly effective in eliciting a dendritic cell-mediated immune response against malignant gliomas. Cancer Res 66: 10247-10252.

PICCIRILLO, S.G., REYNOLDS, B.A., ZANETTI, N., LAMORTE, G., BINDA, E. BROGGI, G., BREM, H., OLIVI, A., DIMECO, F. and VESCOVI, A.L. (2006). Bone morphogenetic proteins inhibit the tumorigenic potential of human brain tumour-initiating cells. Nature 444: 761-765.

PLATE, K.H., BREIER, G., WEICH, H.A., MENNEL, H.D. and RISAU, W. (1994). Vascular endothelial growth factor and glioma angiogenesis: coordinate induction of VEGF receptors, distribution of VEGF protein and possible in vivo regulatory mechanisms. Int J Cancer 59: 520-529.

PLATE, K.H., BREIER, G., WEICH, H.A. and RISAU, W. (1992). Vascular endothelial growth factor is a potential tumour angiogenesis factor in human gliomas in vivo.
Nature 359: 845-848.

SANDLER, A., GRAY, R., PERRY, M.C., BRAHMER, J., SCHILLER, J.H., DOWLATI, A., LILENBAUM, R. and JOHNSON, D.H. (2006). Paclitaxel-carboplatin alone or with bevacizumab for non-small-cell lung cancer. N Engl J Med 355: 2542-2550.

SHAO, E.S., LIN, L., YAO, Y. and BOSTROM, K.I. (2009). Expression of vascular endothelial growth factor is coordinately regulated by the activin-like kinase receptors 1 and 5 in endothelial cells. Blood 114: 2197-2206.

SINGH, S.K., HAWKINS, C., CLARKE, I.D., SQUIRE, J.A., BAYANI, J., HIDE, T., HENKELMAN, R.M., CUSIMANO, M.D. and DIRKS, P.B. (2004). Identification of human brain tumour initiating cells. Nature 432: 396-401.

STCROIX, B., RAGO, C., VELCULESCU, V., TRAVERSO, G., ROMANS, K.E., MONTGOMERY, E., LAL, A., RIGGINS, G.J., LENGAUER, C., VOGELSTEIN, B. et al . (2000). Genes expressed in human tumor endothelium. Science 289: 1197-1202.

VERMEULEN, L., SPRICK, M.R., KEMPER, K., STASSI, G. and MEDEMA, J.P. (2008). Cancer stem cells--old concepts, new insights. Cell Death Differ 15: 947-958.

VISVADER, J.E. and LINDEMAN, G.J. (2008). Cancer stem cells in solid tumours: accumulating evidence and unresolved questions. Nat Rev Cancer 8: 755-768.

WICHA, M.S., LIU, S. and DONTU, G. (2006). Cancer stem cells: an old idea--a paradigm shift. Cancer Res 66: 1883-90; discussion 1895-1896.

XIONG, Y.Q., SUN, H.C., ZHANG, W., ZHU, X.D., ZHUANG, P.Y., ZHANG, J.B., WANG, L., WU, W.Z., QIN, L.X. and TANG, Z.Y. (2009). Human hepatocellular carcinoma tumor-derived endothelial cells manifest increased angiogenesis capability and drug resistance compared with normal endothelial cells. Clinical Cancer Res 15: 4838-4846.

YANG, X.R., XU, Y., YU, B., ZHOU, J., QIU, S.J., SHI, G.M., ZHANG, B.H., WU, W.Z., SHI, Y.H., WU, B. et al. (2010). High expression levels of putative hepatic stem/ progenitor cell biomarkers related to tumour angiogenesis and poor prognosis of hepatocellular carcinoma. Gut 59:953-962.

YAO, X.H., PING, Y.F., CHEN, J.H., XU, C.P., CHEN, D.L., ZHANG, R., WANG, J.M. and BIAN, X.W. (2008). Glioblastoma stem cells produce vascular endothelial growth factor by activation of a G-protein coupled formylpeptide receptor FPR. J Pathol 215: 369-376.

YU, F., YAO, H., ZHU, P., ZHANG, X., PAN, Q., GONG, C., HUANG, Y., HU, X., SU, F., LIEBERMAN, J. et al. (2007). let-7 regulates self renewal and tumorigenicity of breast cancer cells. Cell 131: 1109-1123. 


\section{Further Related Reading, published previously in the Int. J. Dev. Biol.}

Insulin-like growth factor-2 regulates early neural and cardiovascular system development in zebrafish embryos Lori Hartnett, Catherine Glynn, Catherine M. Nolan, Maura Grealy and Lucy Byrnes Int. J. Dev. Biol. (2010) 54: 573-583

The seminal work of Werner Risau in the study of the development of the vascular system Domenico Ribatti Int. J. Dev. Biol. (2010) 54: 567-572

\section{Estrogen regulation of placental angiogenesis and fetal ovarian development during primate pregnancy} Eugene D. Albrecht and Gerald J. Pepe

Int. J. Dev. Biol. (2010) 54: 397-407

Uteroplacental vascular development and placental function: an update Lawrence P. Reynolds, Pawel P. Borowicz, Joel S. Caton, Kimberly A. Vonnahme, Justin S. Luther, David S. Buchanan, Shireen A. Hafez, Anna T. Grazul-Bilska and Dale A. Redmer

Int. J. Dev. Biol. (2010) 54: 355-365

Critical growth factors and signalling pathways controlling human trophoblast invasion Martin Knöfler

Int. J. Dev. Biol. (2010) 54: 269-280

Over-expression of thymosin beta4 promotes abnormal tooth development and stimulation of hair growth Hee-Jae Cha, Deborah Philp, Soo-Hyun Lee, Hye-Sung Moon, Hynda K. Kleinman and Takashi Nakamura Int. J. Dev. Biol. (2010) 54: 135-140

The contribution of Roberto Montesano to the study of interactions between epithelial sheets and the surrounding extracellular matrix Domenico Ribatti Int. J. Dev. Biol. (2010) 54: 1-6

5 yr ISI Impact Factor $(2009)=3.253$

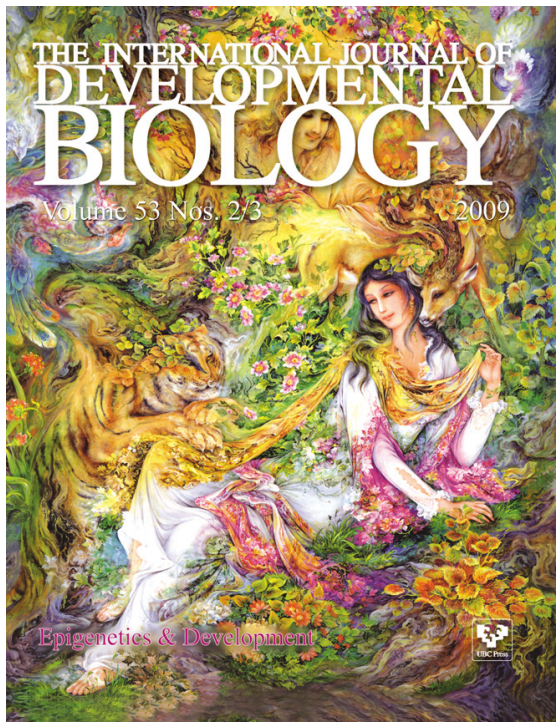

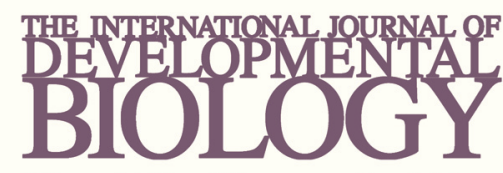

Volume 54 Nos. 6/7
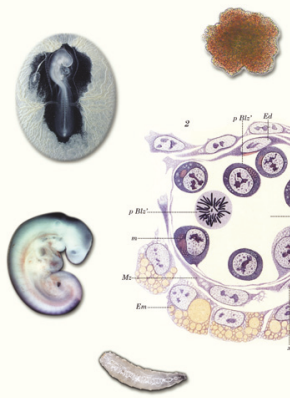

Special Issue
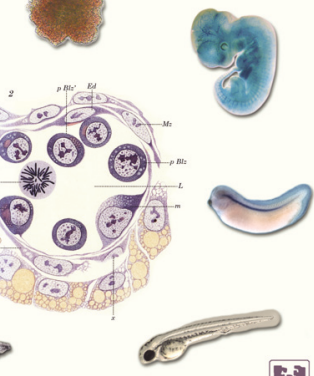

Developmental Hematopoiesis

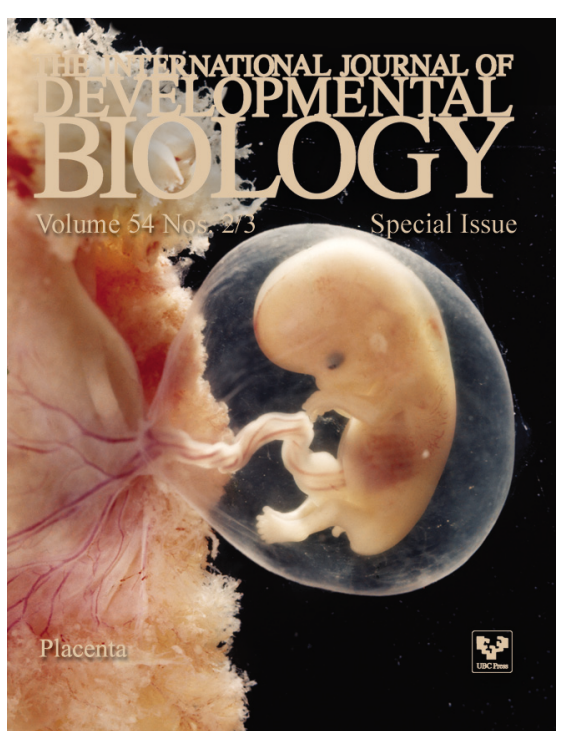

